\title{
HISTORICAL CONSCIOUSNESS AS A PART OF NATIONAL CONSCIOUSNESS: TO THE PROBLEM STATEMENT OF THE RESEARCH
}

\author{
(C) Maxim G. Kuleshin, Natalya A. Leonova, Pavel G. Nemashkalov \\ State Educational Government-Financed Institution of Higher Education \\ "Stavropol state teacher's institute", Stavropol, Russian Federation \\ science-almanac@mail.ru
}

It is known that each new generation addresses the past not only for the purpose of understanding of connections with the past, but also because of the present interests. At any historical stage, there is time when historical figures or events are of great interest. It is noted that most of the peoples pay special attention to the past that obviously coincides with the growth of national consciousness. It has been recently occurred that the attention to the historical past is connected with the judgment of modern realization of the principles of social development. Therefore, from the scientific and practical point of view it makes sense to consider the question about the ratio of historical and national consciousness of the folk. The important place is taken here by the historical memory in the system of historical consciousness. Ethno-social researches allow giving the real vision of the situation in the life of the folk. The vision of the historical past is one of the components of national consciousness if to understand it widely not only as identification of people on the ground of nationality, but also as an image of the folk in general, that is the vision of features of the folk, its culture, past and present and the national interests connected with it. At the same time visions, knowledge of people of this or that community about their past, including mythological knowledge, scientifically got historical data have not been the historical consciousness yet. It is possible to call such knowledge and visions the historical memory. It is an indispensable part of culture in which continuity stabilizes the ethnos. The historical memory is a peculiar spiritual potential of the folk. It can be used, and it is really used sometimes for the benefit of all folk and sometimes of separate social groups.

Key words: historical memory, national interests, social interests, historical knowledge, culture, personality, consciousness.

\section{[М.Г. Кулешин, Н.А. Леонова, П.Г. Немашкалов Историческое самосознание как часть националь- ного самосознания: к постановке проблемы исследования]}

Известно, что каждое новое поколение обращается к прошлому не только с целью осознания связей с минувшим, но и исходя из своих нынешних интересов. На любом историческом этапе бывает время, когда к историческим деятелям или событиям проявляют особый интерес. У большинства народов отмечается повышенное внимание к прошлому, что явно совпадает с ростом национального самосознания. Внимание к историческому прошлому в последнее время оказалось самым непосредственным образом, связанно с осмыслением современной реализации принципов общественного развития. Следовательно, с научной и практической точки зрения имеет смысл рассмотреть вопрос о соотношении исторического и национального самосознания народа. Важное место здесь занимает историческая память в системе исторического самосознания. Реальное представление о положении дел в жизни народа, позволяют дать этносоциологические исследования. Представление об историческом прошлом является одним из компонентов национального самосознания, если понимать его широко - не только как идентификацию людей по национальному признаку, но и как образ народа в целом, то есть представление о чертах народа, его культуре, прошлом и настоящем и связанные с этим национальные интересы. Вместе с тем, представления, знания людей той или другой общности о своем прошлом, в том числе мифологические знания, научно добытые исторические сведения еще не есть историческое самосознание. Такие знания и представления скорее являются тем, что можно назвать исторической памятью. Это непременная часть культуры, преемственность в которой стабилизирует этнос. Историческая память - своеобразный духовный потенциал народа. Он может быть использован, и его реально используют иногда в интересах всего народа, иногда отдельных социальных групп.

Ключевые слова: историческая память, национальные интересы, социальные интересы, исторические знания, культура, личность, сознание. 
Maxim G. Kuleshin - candidate of historical sciences, associate professor. State Educational GovernmentFinanced Institution of Higher Education "Stavropol state teacher's institute", Stavropol, Russian Federation. Natalya A. Leonova - candidate of historical sciences, associate professor. State Educational GovernmentFinanced Institution of Higher Education "Stavropol state teacher's institute", Stavropol, Russian Federation. Pavel G. Nemashkalov - candidate of historical sciences, associate professor. State Educational GovernmentFinanced Institution of Higher Education "Stavropol state teacher`s institute", Stavropol, Russian Federation.

Кулешин Максим Георгиевич - кандидат исторических наук, доцент. Ставропольский государственный педагогический институт, г. Ставрополь, Российская Федерация.

Леонова Наталья Александровна - кандидат исторических наук, доцент. Ставропольский государственный педагогический институт, г. Ставрополь, Российская Федерация.

Немашкалов Павел Григорьевич - кандидат исторических наук, доцент. Ставропольский государственный педагогический институт, г. Ставрополь, Российская Федерация.

The national feelings relying on the historical memory can stir up patriotic sentiments, excite the national dignity of people, and motivate them to vigorous political, social, labor and cultural activity. Unfortunately, the historical memory is sometimes used not only in the progressive purposes, but also for unreasonable glorification and opposition to other people that leads to the negative consequences. The historical memory allows preserving the cultural wealth, which unites the society.

The updated historical memory is also historical consciousness of the folk; it is not only knowledge of events and the phenomena of the past, but also the attitude towards them and also the behavior from such knowledge and such relation. Thus, both in national consciousness in general and in historical consciousness as a part of it or of its element there are three components: informative, emotionally-valuable and regulatory.

The historical consciousness of people of this or that community not always, to be exact, not in everything can coincide with national consciousness. Knowledge of the past of mankind in general, including knowledge of the period before ethnical stages of its development, can go beyond the national consciousness, "it is forms of spiritual and practical development of the world, it expresses the valuable attitude of the person towards the reality" [4, pp. 9-12]. This knowledge helps to realize the place and the role of own folk in historical process, "provides education of the positive attitude towards the cultural distinctions" [2, pp. 7-10].

What updates the historical memory? What makes it the active element of the national consciousness? First of all, national interests which, as we know, usually serve as expression of social interests. Historical knowledge promotes distribution of the ideological and political processes, anyway, happening in the public system. At the same time both historical and national consciousness become mass only when it is widespread in all social groups of the folk. Researchers of many countries consider that both national and historical consciousness becomes real mass during an era when education is generally accessible, and the national ideas are widely opened to all segments of the population by mass media. It, of course, does not mean that in the past the population ethnically did not identify itself and had no ideas of the past. It is known that there were no ethnic communities without the selfname, without consciousness and people showed their patriotism at all times. Speaking about mass national consciousness in its modern understanding, it is meant the consciousness when all or most of members of community have historical knowledge of their folk, these members developed a certain relation to their folk's values under the influence of the state ideology or under the ideas of the leading groups, they are ready to work for the sake 
of common goals and interests. Thus, the understanding of interests of their nation and of their folk takes place.

Various ethno-social researches demonstrate wide spread of historical consciousness as a part of national consciousness. The known indicator of this was the interest of people in literature about the past of their folk, being a part of history.

By popularity of literature about the past of the folk, it is possible to consider the historical memory of the folk to a certain extent. Data about historical and cultural events reflected in professional historical and literary works is transmitted from generation to generation. Each person or social group has a various volume of the historical memory. This variety depends on education, the width of common cultural knowledge, and sometimes it depends on the ability to memorizing. But the updating of historical, cultural events and phenomena depends on the certain circumstances, and first of all on the social and political situations which make national consciousness active, and sometimes aggravating, which defines "the need of consideration ... disposition of social structures" [1, pp. 168-177]. Thus, small peoples more often have more active historical memory.

As a rule, this phenomenon is promoted by knowledge of outstanding historical figures for which the peoples have special regard and literary interests. The deep and broad historical memory cannot be developed only by basic education and mass media. This historical memory was being laid in the course of the long historical development of these or those peoples.

Cultural and historical events are usually realized by the people not only as a part of their past, in relation to them the subjective feeling of connection and continuity of traditions which are connected with "public consciousness ... of the general cultural norms and values" arise [6, page 6-12]. In general, both the conscious relation to historical events, values, and the feelings connected with such relation are the manifestation of the national consciousness.

History knows a lot of examples when the aura of national heroes was created around the names of historical figures or cultural figures; they became a symbol of national movements.

Among outstanding figures there are names of writers, poets, artists, composers and cultural figures of their nationality. It is possible to claim that cultural figures strongly enter the historical memory of the peoples.

The special popularity is gained by the outstanding figures of literature and art among those peoples whose professional culture was actively formed during various historical periods of society development [3, pp. 45-49]. They become a symbol of national pride. Huge editions of their works, screen versions, theatrical performances based on their works, speak about the popularity of national writers.

It is also important to note the fact that the attention to the history and the culture of the peoples is expressed in visiting the historical and ethnographic museums. In the field of socio-historical development, the museums of history and archeology, the museums of folk art and ethnography are especially relevant here. The interest in historical monuments and the museums is especially big among qualified national groups. It is possible to tell that families in which parents usually encourage their children in reading historical literature and watching historical movies, promote the formation of the historical memory. Most likely, in such families there is an aspiration to give to the children not only common cultural knowledge, but also the national consciousness. It is possible to judge about the steady preservation of interest in the history among the peoples also on the basis of the people's relation to the radio and television programs about their history.

The historical memory includes not only events of bygone, but also closer time and to some extent even the present moment. Not without reason it is said about present history. 
Everybody is interested in modern life of their folk. This interest is especially developed among the national groups living outside their ethnic environment. Such interest in life of their nation demonstrates, obviously, understanding of connection with it, feeling of participation in its achievements.

The cultural arsenal included in the historical memory, as well as the events of the historical past and the historical present, enter the modern image of the folk as a significant component, like an idea of some typical features of the folk, what is called a national autostereotype. It is a kind of a potential stock of the national consciousness. It can work, begin to work, set in motion and direct the people's actions or it can remain not updated depending on an economic, social and political situation. The role of the historical memory increases in modern conditions when the base of national consciousness in parameters of traditional culture is narrowed. Besides, the national consciousness quite often reanimates memories of the past, and it is not always adequate to the real events.

The materials of concrete social researches to a certain extent give the data of the impact of cultural progress on the growth of national and historical consciousness. The feature set according to which people identify themselves with their ethnos is much fuller and more various with the growth of education and qualification in social groups, especially among experts with the higher education.

Except education, the development of national consciousness stimulates familiarizing with literature and information about their own and other peoples which is being transferred by mass media.

Knowledge as a result of the reflection of socio-historical practice and also of the personality awareness defines not only such element of national consciousness as national self-identification, but also other its elements: ideas of community of origin, of historical destiny, of the territory of resettlement which immeasurably extend with the increase of education level and cultural activity of the personality [7, pp. 15-18] in the context of "formation of new social reality" [8, pp. 64-68]. It is shown that the community of historical destiny is mentioned as a sign that makes related with their folk by the representatives of more literate layers of the population.

International engagement in modern conditions undoubtedly promotes not only the national identification, but also the growth of national consciousness in general. The question about the activity of its influence and its importance among other factors demands special studying. International engagement really promotes formation of national consciousness. During international communication, the potential of national consciousness among people is higher, than in the one-national environment, but this potential is not always and not necessarily widely used and it is not exaggerated. In such situation, everything depends on a social, political, cultural and religious situation of international communication. There are cases when during not increasing international communication, and with not such high potential of national consciousness among the folk, it suddenly gives extraordinary splashes.

Not the last role is played here by the cultural characteristics: language, customs, religion which "emphasizes the influence on the philosopher of the theological ideas ..." [5, pp. 29-31], notes "the influence of Orthodoxy on formation and registration of the Russian culture" [9, pp. 39-44] and also ceremonies, professional culture as well as the auto stereotypes basic for understanding of identification and national consciousness in general, expression of tension in the international relations, sharpening of national consciousness. It can be promoted by the social growth of the nation, increase of the share of educated people, of the intellectuals and of skilled workers. At the same time such situation can arise because of deformation in the social and economic and political sphere. On this background, without the will of the population, it is capable to become the catalyst of transferring of social 
dissatisfaction onto the national soil. The surge of national consciousness and national feelings can provoke a conflict situation.

The historical memory as the source feeding historical and national consciousness at the moments of mass national actions, of difficult socio-political situations when the interests of one nation face the interests of another nation is especially updated. The examples are the events in connection with the movement in Nagorno-Karabakh for the accession to Armenia at the end of 1987, in 1988-1989 of the 20th century. The attention of not only historians of Armenia and Azerbaijan, but also of very wide circles of the population in these republics and beyond their limits was drawn to the historical fate of this area. Tragic events in Sumgait aggravated the historical memory about genocide times. Historic facts were discussed not less widely and hotly, than questions of self-determination, of economic situation and cultural development of Armenians of Nagorno-Karabakh. National interests had reanimated the historical memory.

The memory of the historical events and the phenomena of the past can become a powerful source for public moods and expression of national consciousness among various peoples.

As a rule, the formation of new historical consciousness for all peoples is connected with reconsideration of historical experience. This process demands the comprehensive study.

It is possible to claim that the high potential of national consciousness allows social forces to choose from it that stock which will be especially effective in a concrete situation. Leaning on feeling of national pride and national and specific personal values of every folk, it is possible to achieve success, using them as additional incentives, for example, for increase of public and professional activity. It is known that in the conditions of various transformations the efforts directed to intensifying of the fully formed orientations onto the certain activity, addressing production traditions of the old production centers and the best practices of the modern enterprises of the first echelon of scientific and technical progress can be made. At the same time, the address of domestic writers to the revival of high moral principles of the folk, to the raising of national feelings for improvement of our life, finds support in different sectors of society. The public of these or those peoples directs the conscious national unity to fight against the negative phenomena, deformations in the personnel policy and in the moral sphere. The Central Asian people highly appreciate the respect of surrounding people. It can be used as the mechanism of increase in responsibility of people to raise efficiency of economic activity and to improve the moral atmosphere in various public collectives.

The usage of the spiritual potential of each nation accumulated by the national consciousness and the actuation of this potential for the benefit of progress are difficult and responsible tasks of society. For management of these capacious processes the following conclusions can matter.

With a trend for reduction of ethnic and specific things in the peoples' life, their national consciousness grows. This results from the fact that the objective base for the formation of national consciousness does not come down only to traditional, ethnic and specific culture. It also includes modern culture and professional culture, which is actively developed among the peoples. Besides, the formation of national consciousness goes on the basis of reflection in consciousness of people of such objective phenomenon that all peoples have their own historical past, territories of resettlement, at last, all social and economic, political, cultural factors around which the national interests concentrate. The growth of national consciousness objectively depends on the level of social and economic and cultural development of the peoples, on the people's world outlook, on the expansion of spheres of their activity and interethnic direct and intermediate contacts. The created and grown national con- 
sciousness among the modern peoples is a kind of a part of their spiritual arsenal. It can be not updated, potential, and under the certain social, political conditions, it can become more active. The positive or negative sense of such activity depends, first of all, on the purposes to which the people's actions are directed. In the case of concentration of national interests on the egocentric purposes, the updated national consciousness can isolate the peoples, tend to manifestations of regionalism and national isolation, and complicate the international relations. But it is worth to remember that the active national consciousness, understanding of the historic responsibility, pride of the folk, and the interest of people in progress of their activity enhance their social and public enthusiasm, can serve social progress of the nation and of all folk.

\section{Лumepamypa}

1. Бакланова О.А. Бакланов И.С. Современная российская социальность в контексте социального конструкционизма // Вопросы социальной теории. 2015. Т. 7. № 1-2. С. 168-177.

2. Говердовская Е.В. Особенности проектирования образовательного пространства высшей школы в поликультурном регионе // Экономические и гуманитарные исследования регионов. 2014. № 4. С. 7-10.

3. Гончаров В. Н. Социальный аспект религии в контексте развития первобытного общества // Гуманитарные и социально-экономические науки. 2016. № 2 (87). С. 45-49.

4. Ерохин А.М. Религия и искусство в системе культуры // European Social Science Journal. 2014. № 7-2 (46). C. 9-12.

5. Камалова О.Н. «Созерцание» в философско-культурологических построениях И. Ильина // Гуманитарные и социально-экономические науки. 2012. № 6. С. 29-31.

6. Колосова О.Ю. Духовная сфера: универсализм и самобытность // European Social Science Journal. 2012. №11-2(27). C. 6-12.

7. Лобейко Ю.А. Социально-педагогический аспект активности личности в системе общественного развития // Экономические и гуманитарные исследования регионов. 2015. № 1. С. 15-18.

8. Лукьянов Г.И. Трансформационные процессы в современном российском обществе как отражение динамики новой социальной реальности // Экономические и гуманитарные исследования регионов. 2017. № 4. С. 64-68.

9. Матяш Т.П., Несмеянов Е.Е. Православный тип культуры: идея и реальность // Гуманитарные и социально-экономические науки. 2015. № 3 (82). С. 39-44.

\section{References}

1. Baklanova O.A. Baklanov I.S. Sovremennaia rossiiskaia sotsial'nost' v kontekste sotsial'nogo konstruktsionizma. Voprosy sotsial'noi teorii [Modern Russian sociality in the context of a social constructionism. Questions of the social theory]. 2015. V. 7. No. 1-2. pp. 168-177 (in Russian).

2. Goverdovskaia E.V. Osobennosti proektirovaniia obrazovatel'nogo prostranstva vysshei shkoly v polikul'turnom regione. Ekonomicheskie i gumanitarnye issledovaniia regionov. [Features of design of educational space of the higher school in the polycultural region. Economic and humanitarian researches of regions]. 2014. No. 4. pp. 7-10 (in Russian).

3. Goncharov V.N. Sotsial'nyi aspekt religii v kontekste razvitiia pervobytnogo obshchestva. Gumanitarnye i sotsial'no-ekonomicheskie nauki [Social aspect of religion in the 
context of development of primitive society. Humanitarian and social and economic sciences]. 2016. No. 2(87). pp. 45-49 (in Russian).

4. Erokhin A.M. Religiia $\mathrm{i}$ iskusstvo $v$ sisteme kul'tury [Religion and art in the system of culture.]. European Social Science Journal. 2014. No. 7-2 (46). pp. 9-12.

5. Kamalova O.N. "Sozertsanie' v filosofsko-kul'turologicheskikh postroeniiakh I. Il'ina Gumanitarnye i sotsial'no-ekonomicheskie nauki ["Contemplation" in philosophical and culturological creation of I. Ilyin. Humanitarian and social and economic sciences]. 2012. No. 6. pp. 29-31(in Russian).

6. Kolosova O Iu. Dukhovnaia sfera: universalizm i samobytnost'. European Social Science Journal [Spiritual sphere: universalism and originality. European Social Science Journal] 2012. No.11-2 (27). pp. 6-12.

7. Lobeiko Iu.A. Sotsial'no-pedagogicheskii aspekt aktivnosti lichnosti v sisteme obshchestvennogo razvitiia. Ekonomicheskie i gumanitarnye issledovaniia regionov [Social and pedagogical aspect of activity of the personality in the system of social development. Economic and humanitarian researches of regions]. 2015 No.1. pp.15-18 (in Russian).

8. Luk'ianov G.I. Transformatsionnye protsessy v sovremennom rossiiskom obshchestve kak otrazhenie dinamiki novoi sotsial'noi real'nosti. Ekonomicheskie i gumanitarnye issledovaniia regionov [Transformational processes in modern Russian society as reflection of dynamics of new social reality. Economic and humanitarian researches of regions]. 2017. No. 4. pp. 64-68 (in Russian).

9. Matiash T.P., Nesmeianov E.E. Pravoslavnyi tip kul'tury: ideia i real'nost'. Gumanitarnye i sotsial'no-ekonomicheskie nauki [Orthodox type of culture: idea and reality. Humanitarian and social and economic sciences]. 2015. No. 3 (82). pp. 39-44 (in Russian).

20 February, 2019 